\title{
Design and Implementation Buck Converter for 540WP Solar Charger Using Fuzzy Logic Control
}

\author{
Sutedjo ${ }^{1, *}$, Ony Asrarul Qudsi ${ }^{1}$, Andi Ardianto ${ }^{1}$, Diah Septi Yanaratri ${ }^{1}$, Suhariningsih ${ }^{1}$, Moch. Darwis ${ }^{1}$ \\ ${ }^{1}$ Electrical Engineering Department Politeknik Elektronika Negeri Surabaya, Indonesia
}

\begin{abstract}
This paper presents the details of design and implementation of DC-DC Buck converter as solar charger. This converter is designed for charging a battery with a capacity of 100 Ah (Ampere Hours) which has a charging voltage of 27.4 volts. The constant voltage method is selected on battery charging with the specified set point. To ensure the charging voltage is always on the set point, the duty cycle control of buck converter is set using Fuzzy Logic Control (FLC). The design implementation has been tested on PV (photovoltaic) with 540WP capacity. Based on the test results, this method is quite well implemented on the problem charger.
\end{abstract}

\section{Introduction}

The increasing energy demand and the declining availability of fossil energy sources led to the rapid development of alternative energy. One of the most widely used alternative energy sources is solar energy [1]-[3]. The transformation of energy sources from fossils into solar energy sources has had a considerable impact on the development of power electronics products. Batteries are energy storage that is included in power electronics products. Batteries are widely used in various applications, such as telecom power supplies, electric vehicles, UPS (uninterruptible power supplies), photovoltaic systems, portable electronic products, and others [12]-[13]. The charging process of a battery plays an important role because it can affect the durability and capacity of the battery that indirectly also affect the battery life. Many engineers and researchers look for simple, effective, and economical methods to solve this problem. Different types of battery charging approach show different efficiency values.

Conventional charging will result in losses due to power dissipation in the process of charging the battery. The conventional charging process is done by converting power from AC source to DC source [4]. The use of this method requires the rectifier of the thyristor converter which will convert the AC source into DC, with the addition of series resistance to control the flow of power in the charging process. This battery charging method will of course produce a very high ripple current. This method has poor efficiency when applied on a large scale. Such conditions cause concerns about the quality of the battery charger to increase, so it takes a battery charging circuit that can reduce the ripple and prolong battery life.

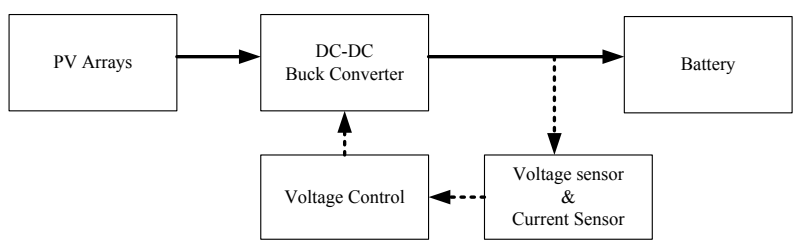

Fig. 1. The topology of battery charging

This research proposes a battery charging process by utilizing solar energy sources. The topology of proposes a battery charging show in Figure 1. Generally, the energy collected in PV arrays is used as a charger source. However, the PV output voltage arrays vary according to the existing sunlight. Unstable PV arrays output voltage can shift the operating point of the charger. Therefore, this study designed a new approach with Buck Converter as DC-DC converter which has been widely applied to DC motor speed regulator and energy backup system will be implemented in battery charging system [5]-[11]. In this research, the implementation of DC-DC converter is used as battery charging system for battery charging using constant voltage method where the output voltage is set at the desired set point so that the output voltage becomes fixed and the current generated follows the input power.This means that the output voltage of the buck converter that always at setpoint will make the input voltage for battery charging stable. Such conditions will indirectly affect the battery power and battery life. Figure 1 illustrates the topology of a battery charging system with a solar energy source. Buck Converter is used for battery charging with capacity of $100 \mathrm{Ah}$ and charging voltage of $27.4 \mathrm{~V}$ with an input power supply of 540WP PV. To keep the charging voltage always on the setpoint, the duty cycle on the buck converter will be set using Fuzzy Logic Control (FLC). Of the various 
intelligent controllers, the FLC is the simplest and better control than conventional controllers in terms of insensitivity to parameter variations, time response, and resilience [16]-[18]. Furthermore FLC is an adaptive control technique that allows to change the duty cycle buck converter parameters under unstable PV voltage output conditions. The design then implemented so that prototype solar charger can be used for charging the battery with the stable input voltage.

\section{Buck Converter Design for Solar Charger}

Buck converter has the characteristic of lowering DC voltage by adjusting duty cycle (D) by switching process using a semiconductor. The buck converter circuit is shown in Figure 2.

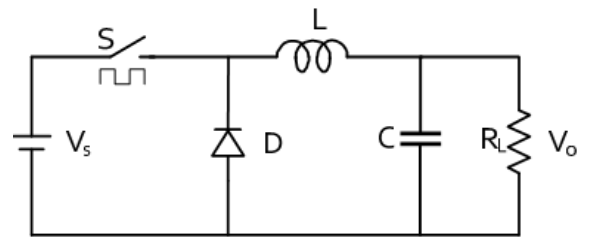

Fig. 2. Buck converter circuit.

When the switch is open, the output gets energy from the capacitor and from the inductor. The circuit when the switch is open is shown in Figure 3 (a).

$$
\begin{aligned}
& V_{L}=-V_{o} \\
& V_{L}=L \frac{d i_{L}}{d t} \\
& \frac{d i_{L}}{d t}=\frac{-V_{O}}{L}
\end{aligned}
$$

Changes in the inductor current are:

$$
\begin{aligned}
& \frac{d i_{L}}{d t}=\frac{\Delta i_{L}}{\Delta t} \\
& \frac{d i_{L}}{d t}=\frac{\Delta i_{L}}{(1-D) T}
\end{aligned}
$$

The solution for $\Delta i \mathrm{~L}$ for open switches is:

$$
\Delta i_{L}(\text { open })=\frac{\left(-V_{o}\right)(1-D) T}{L}
$$

When the switch is closed the diode is in reverse biased position. The output is isolated and the input supplies energy to the inductor, the circuit shown in Figure 3 (b).

The inductor voltage is:

$$
V_{L}=V_{s}-V_{o}
$$

$$
\frac{d i_{L}}{d t}=\frac{V_{S}-V_{O}}{L}
$$

The change in the inductor current is:

$$
\frac{d i_{L}}{d t}=\frac{\Delta i_{L}}{D T}
$$

The solution for $\Delta i L$ for closed switches is:

$$
\Delta i_{L}(\text { closed })=\frac{\left(V_{S}-V_{O}\right) D T}{L}
$$

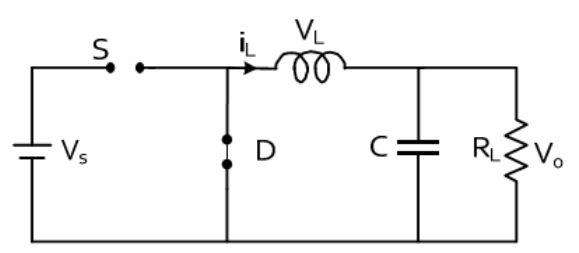

(a)

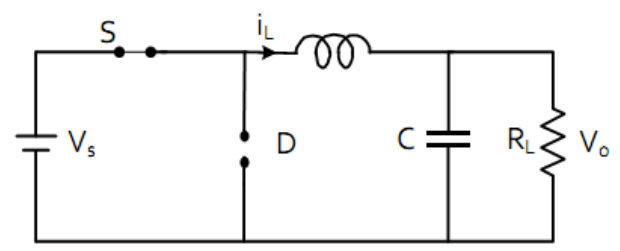

(b)

Fig. 3. (a) Buck converter circuit when the switch is open, (b) Buck converter circuit when the switch is closed

The method of battery charging proposed in this research is constant voltage method. This method is chosen to keep the dry battery from over-charged. Therefore, definite voltage control and proper charging time in the battery charging method is essential to maintain expected battery life time. The charging voltage for a $100 \mathrm{Ah}$ battery is $13.8 \mathrm{~V}-14.7 \mathrm{~V}$. Determination of the charging voltage is obtained from the battery capacity by State of Charge (SoC). The charging voltage of 13.7 Volts has reached $90 \%$ of the battery voltage in full condition. The design of buck converter output power is based on charging current and voltage charging of the battery. Parameter of buck converter show in table 1 .

Table 1. Basic Parameter of Buck Converter

\begin{tabular}{|l|c|c|}
\hline \multicolumn{1}{|c|}{ Parameter } & Unit & Value \\
\hline Input Voltage $\left(\mathrm{V}_{\mathrm{s}}\right)$ & Volt & 55.4 \\
\hline Output Voltage $\left(\mathrm{V}_{\mathrm{o}}\right)$ & Volt & 27.4 \\
\hline Output Current $\left(\mathrm{I}_{\mathrm{o}}\right)$ & Ampere & 13.795 \\
\hline Voltage Ripple & $\%$ & 0.1 \\
\hline Current Ripple & $\%$ & 20 \\
\hline Maximal Input Power & $\mathrm{WP}$ & 361 \\
\hline Switching Frequency & $\mathrm{kHz}$ & 40 \\
\hline
\end{tabular}




\subsection{Inductor Design}

The inductor can be modeled like the equivalent circuit in Figure $4 . R$ is the DC resistance of the coil. Then the inductor can produce inductance and resistance $R$ on the coil. The inductor is not saturated when using the worst case of $I_{\max }$ 's peak current. As a note the relationship between $R$.

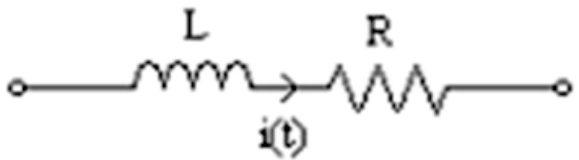

Fig. 4. Inductor model

The resistance of the inductor coil affects the efficiency and output voltage of the converter. Thus, the converter design requires the construction of an inductor with a fairly small coil resistance.

Iinductor values isdetermined using equation (11):

$$
L=\left(\frac{1}{f}\right) x\left(V i n_{-} \max -V o\right) x\left(\frac{V o+V f}{V i n \_\max +V f}\right) x\left(\frac{1}{\Delta_{I L}}\right)
$$

Where:

$L \quad$ : Inductance value (Henry)

Vin : Input Voltage (Volt)

Vo : Output Voltage (Volt)

$V f \quad$ : Diode falling Voltage(Volt)

$\Delta i L$ :Ripple current (Ampere)

The number of inductor windings is obtained using equation (12):

$$
N=\frac{L \times \operatorname{Im} a x}{B \max \times A c}
$$

Where :

$$
\begin{array}{ll}
\mathrm{N} & : \text { Number of turn } \\
\mathrm{Bmax} & : \text { Magnetic field (Tesla) } \\
\mathrm{Ac} & : \text { core cross-section area }\left(\mathrm{mm}^{2}\right)
\end{array}
$$

The average current and the maximum current of the inductor can be calculated using the equations (13) and (14):

$$
\begin{aligned}
& I_{L}(\operatorname{avg})=I_{o}=\frac{V o}{R} \\
& \operatorname{Im} a x=I_{L}+\frac{\Delta_{I L}}{2}
\end{aligned}
$$

Where:

$$
\begin{array}{ll}
I_{L}(a v g) & : \text { Inductor average current (Ampere) } \\
I o & : \text { Output current (Ampere) } \\
V o & : \text { Output Voltage (Volt) } \\
R & : \text { Resitance (Ohm) } \\
I_{\text {Imax }} & : \text { Inductor maximum current (Ampere) } \\
\Delta I_{L} & : \text { Inductor ripple current (Ampere) } \\
I_{L} & : \text { Inductor current (Ampere) }
\end{array}
$$

To calculate the length of the wire of each split, equation (16) can be used:

$$
\begin{aligned}
& A W G=\frac{\sqrt{I_{i n}{ }^{2}+\left(\frac{\Delta I_{L} / 2}{\sqrt{3}}\right)^{2}}}{n} \\
& l=((n \times k)+40 \%(n \times k)) \times n
\end{aligned}
$$

Where:

$$
\begin{array}{ll}
l & : \text { length of the wire (m/split) } \\
n & : \text { number of split } \\
k & : \text { Bobbin's Circumference (mm) } \\
A W G & : \text { standard wire gauge (Ampere) }
\end{array}
$$

Cross Sectional Area of wire (qw) and wire diameter can be calculated using the following equations (17) and (18):

$$
\begin{aligned}
& q w=\frac{I_{L}}{J} \\
& d w=\sqrt{\frac{4}{\pi} \times q w}
\end{aligned}
$$

Where:

$J \quad$ : Magnetic Energy $\left(\mathrm{A} / \mathrm{mm}^{2}\right)$

$Q w:$ Cross Sectional Area of wire $\left(\mathrm{mm}^{2}\right)$

$D w:$ Wire diameter $(\mathrm{mm})$

From the design results obtained parameters of the inductor according to Table 2 .

Table 2. Parameter of Inductor

\begin{tabular}{|c|c|c|}
\hline Parameter & Unit & Value \\
\hline$I L$ (avg) & Ampere & 13.79 \\
\hline$V o$ & Volt & 27.4 \\
\hline$R$ & Ohm & 1.987 \\
\hline$L$ & $\mu \mathrm{H}$ & 128.57 \\
\hline$I m a x$ & Ampere & 15.169 \\
\hline$N$ & Turn & 11 \\
\hline$A W G$ & Ampere & 1.392 \\
\hline$l$ & $\mathrm{~m} / \mathrm{split}$ & 1.155 \\
\hline$q w$ & $\mathrm{~mm}{ }^{2}$ & 0.309 \\
\hline$d w$ & $\mathrm{~mm}$ & 0.65 \\
\hline
\end{tabular}

\subsection{Capasitor Design}

In this research, the design of capacitor parameters includes the output voltage ripple $(\Delta \mathrm{Vo})$ and capacitor capacitance (Co). Equation (20) shows the relation of the output voltage $(\Delta \mathrm{Vo})$ and the capacitance value of the capacitor $(\mathrm{Co})$.

$$
\Delta V_{o}=\frac{\Delta Q}{C_{o}}=\frac{\Delta_{I L} T}{8 C_{o}}
$$




$$
\begin{array}{cl}
\text { Where: } & \\
\Delta V_{o} & \text { : output voltage ripple (Volt) } \\
T & \text { :switching period (Second) } \\
C_{o} & \text { : output capacitor (Farad) }
\end{array}
$$

From the design results obtained parameters of the capacitor according to Table 3 .

Table 3. Parameter of capacitor

\begin{tabular}{|l|c|c|}
\hline \multicolumn{1}{|c|}{ Parameter } & Unit & Value \\
\hline$\Delta V_{o}$ & Volt & 27.4 \\
\hline$C_{o}$ & $\mu \mathrm{F}$ & 47 \\
\hline
\end{tabular}

\section{Fuzzy Logic Control for Buck Converter}

In this research, input from FLC used is input voltage which consist of input error and $\Delta$ error. Figure 5 shows the membership function of $\Delta$ error. The rules base is following the general behavior of the system written in the linguistiq label membership function pattern. The system output of the planned rule consists of 25 rules shown in the table 4 .

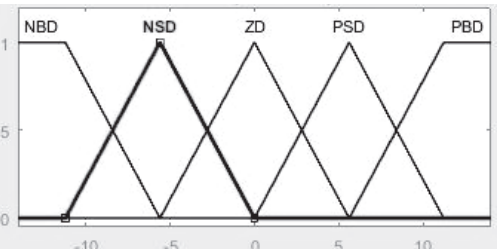

Fig. 5. Membership function $\Delta$ error

Table 4. Rule Base FLC For Buck Converter

\begin{tabular}{|c|c|c|c|c|c|}
\hline \multicolumn{5}{|c|}{ RULE BASE FUZZY LOGIC } \\
\hline $\begin{array}{c}\text { Delta } \\
\text { Error }\end{array}$ & NBE & NSE & ZE & PSE & PBE \\
\hline NBD & NXO & NXO & NBO & NSO & ZO \\
\hline NSD & NXO & NBO & NSO & ZO & PSO \\
\hline ZD & NBO & NSO & ZO & PSO & PBO \\
\hline PSD & NSO & ZO & PSO & PBO & PXO \\
\hline PBD & ZO & PSO & PBO & PXO & PXO \\
\hline
\end{tabular}

If the error condition is NBE and $\triangle$ error NBD, then the output voltage is now greater than the requested output voltage. Therefore the voltage must be lowered larger. So for the first rule is: if error is NBE and Derr is NBD then PWM is NXO.

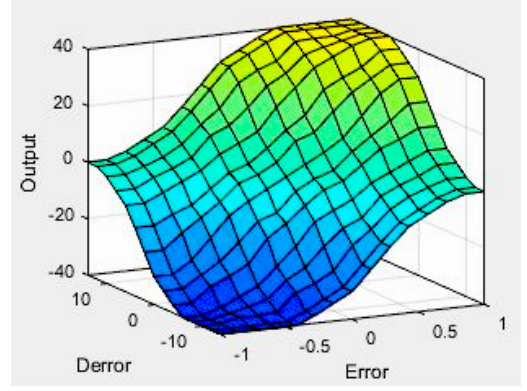

Fig. 6. Surface of rule base

From the results of the rule base obtained then we can see linearization of rules that we make that seen in Figure 6.

\section{Experimental Result}

Testing is intended to get an evaluation of the circuit, in order to obtain better performance. Better performance is achieved by making improvements to the composition of the circuit that experienced a known error during the test. The test method is done into two stages, they are partial testing and integration testing. Partial testing is intended to test the suitability of each part of the design. Partial testing includes solar panel testing and buck converter testing. Further testing is done by integrating PV, buck converter, and battery.

\subsection{PV Testing}

Testing of PV in this study using 4 pieces of 135 WP solar panels that are connected parallel between the two solar panels. The purpose of this parallel relationship is to obtain the maximum current value between the two PV modules. From the PV testing is found that the value of the voltage on average bright conditions is 55.4-35.9 volts.

\subsection{Buck Converter Testing}

The buck converter circuit testing aims to determine the performance of the buck circuit that has been designed and made. Figure 7 is a trigger waveform after being inserted on the Gate-Source MOSFET pin with a $30 \%$ duty cycle. There is a voltage ripple that can reduce the efficiency of a device. In Figure 7 it can also be seen that the buck converter circuit has worked. Where the characteristics of the buck converter work are the occurrence of the oscillation waveform before the drainSource wave touches the zero value.

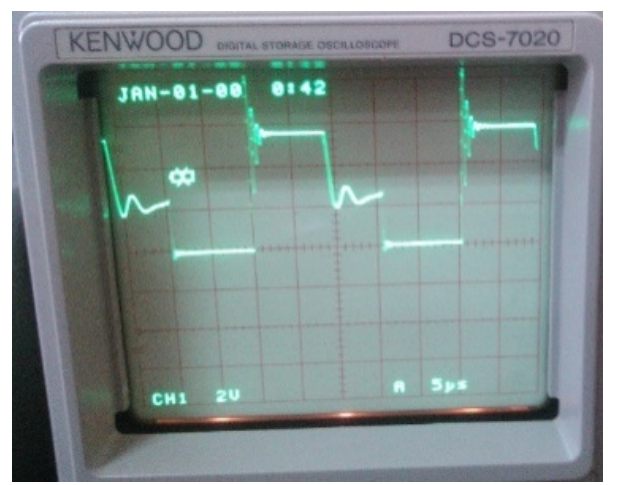


Fig. 7. Drain-Source MOSFET Buck Converter ( $D=30 \%)$ Volt/div : 2 V, Time/div:5us

After the trigger waveform can be generated, the test buck converter circuit will use an input voltage supply of $55.4 \mathrm{~V}$ with a resistive load of $100 \mathrm{~W}$ and use the digital PWM of the microcontroller as the switching trigger of the buck converter circuit.

Table 5. buck converter circuit testing result

\begin{tabular}{|c|c|c|c|c|c|c|c|}
\hline $\begin{array}{c}\text { D } \\
(\%)\end{array}$ & $\begin{array}{c}\text { Vin } \\
(\mathbf{V})\end{array}$ & $\begin{array}{c}\text { Iin } \\
(\mathbf{A})\end{array}$ & $\begin{array}{c}\text { Pin } \\
\mathbf{( W )}\end{array}$ & $\begin{array}{c}\text { Vo } \\
(\mathbf{V})\end{array}$ & $\begin{array}{c}\text { Io } \\
(\mathbf{A})\end{array}$ & $\begin{array}{c}\text { Po } \\
(\mathbf{W})\end{array}$ & $\tilde{\mathbf{\eta}} \mathbf{( \% )}$ \\
\hline 30 & 55,4 & 0,18 & 10,24 & 15,84 & 0,57 & 9,02 & 88,09 \\
\hline 40 & 55,4 & 0,35 & 19,72 & 27,55 & 0,69 & 19,00 & 96,38 \\
\hline 41,4 & 55,4 & 0,37 & 20,77 & 28,76 & 0,70 & 20,13 & 96,90 \\
\hline 50 & 55,4 & 0,48 & 26,59 & 34,46 & 0,74 & 25,67 & 96,54 \\
\hline 60 & 55,4 & 0,55 & 30,52 & 38,06 & 0,77 & 29,49 & 96,63 \\
\hline 70 & 55,4 & 0,65 & 36,28 & 43,70 & 0,81 & 35,39 & 97,54 \\
\hline 80 & 55,4 & 0,88 & 49,25 & 55,00 & 0,89 & 48,95 & 99,39 \\
\hline
\end{tabular}

Based on Table 5, the efficiency generated in the buck converter circuit is greater when the dutycycle used is greater. This is because the value of DC resistance of the inductor has a large enough value so that in the small dutycycle has big losses, thus affecting the efficiency of the buck converter. However, based on the partial experimental data that has been done, the buck converter circuit works well.

\subsection{Integrated Test Buck Converter for Solar Charger}

Integrated testing is done by connecting the PV as the input source of the Buck converter, then the output voltage of the buck converter will serve as the voltage for charging the battery. The initial battery voltage is 24.28 Volts and the rated charging voltage is set at 27.4 Volts, with duty cycle control to adjust the output voltage of the buck converter. Table 6 and 7 shows the results of battery charging using 4 pieces of PV with each 135WP PV capacity.

From the test data shown by table 6 , the test uses manual duty cycle arrangement. Adjustment of duty cycle with the desired output voltage resulted in less good value of efficiency.

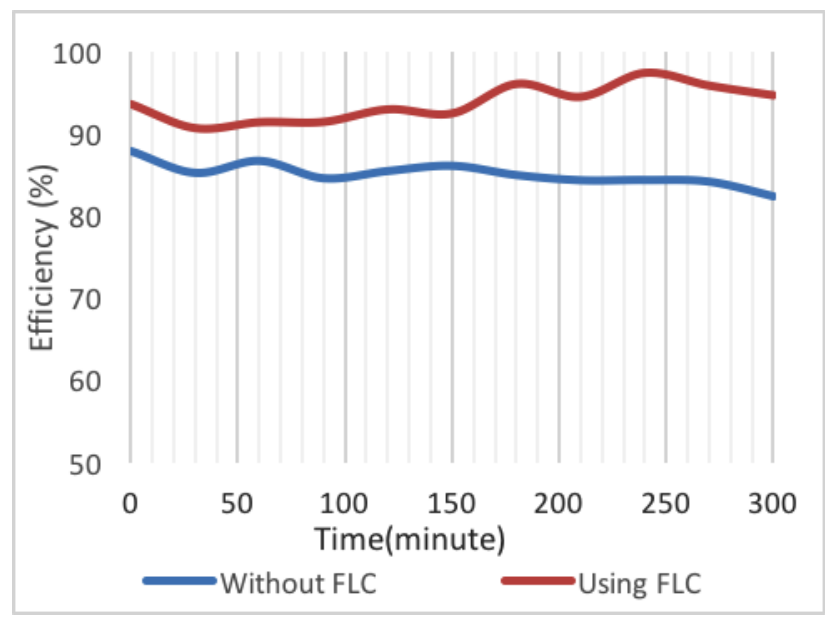

Fig. 8. Efficiency of the buck converter without FLC and using FLC

Table 6. open loop testing result Of Buck Converter (without FLC)

\begin{tabular}{|c|l|l|l|l|l|l|l|l|}
\hline $\begin{array}{c}\text { Vin } \\
(\mathbf{V})\end{array}$ & $\begin{array}{c}\text { Vo } \\
(\mathbf{V})\end{array}$ & $\begin{array}{c}\text { Iin } \\
(\mathbf{A})\end{array}$ & $\begin{array}{c}\text { Io } \\
(\mathbf{A})\end{array}$ & $\begin{array}{c}\text { Pin } \\
(\mathbf{W})\end{array}$ & $\begin{array}{c}\text { Pout } \\
(\mathbf{W})\end{array}$ & $\begin{array}{c}\tilde{\mathbf{n}} \\
\mathbf{( \% )}\end{array}$ & lux & D \\
\hline 47.5 & 27.40 & 4.0 & 6.10 & 190.0 & 167.1 & 87.97 & 892 & 68 \\
\hline 48.5 & 27.35 & 3.8 & 5.75 & 184.3 & 157.2 & 85.33 & 897 & 65 \\
\hline 48.4 & 27.38 & 3.6 & 5.46 & 174.2 & 149.4 & 86.79 & 902 & 64 \\
\hline 49.1 & 27.32 & 3.4 & 5.25 & 169.4 & 143.4 & 84.67 & 892 & 64 \\
\hline 49.7 & 27.38 & 3.1 & 4.85 & 154.0 & 132.7 & 86.19 & 872 & 63 \\
\hline 49.8 & 27.42 & 2.9 & 4.48 & 144.4 & 122.8 & 85.06 & 841 & 63 \\
\hline 49.9 & 27.41 & 2.7 & 4.15 & 134.7 & 113.7 & 84.43 & 824 & 62 \\
\hline 50.9 & 27.42 & 2.5 & 3.92 & 127.2 & 107.4 & 84.46 & 795 & 61 \\
\hline 50.5 & 27.38 & 2.4 & 3.73 & 121.2 & 102.1 & 84.26 & 813 & 60 \\
\hline 51.3 & 27.38 & 2.1 & 3.31 & 107.7 & 90.63 & 84.12 & 875 & 59 \\
\hline 51.1 & 27.40 & 2.0 & 3.04 & 102.2 & 83.30 & 81.50 & 798 & 58 \\
\hline 50.7 & 27.42 & 1.7 & 2.57 & 86.19 & 70.47 & 81.76 & 756 & 59 \\
\hline 51.1 & 27.42 & 1.6 & 2.46 & 81.76 & 67.45 & 82.50 & 747 & 57 \\
\hline 51.0 & 27.38 & 1.6 & 2.40 & 81.60 & 65.71 & 80.53 & 751 & 57 \\
\hline 50.1 & 27.40 & 1.5 & 2.34 & 75.15 & 64.12 & 85.32 & 536 & 59 \\
\hline 50.0 & 27.41 & 1.5 & 2.29 & 75.00 & 62.77 & 83.69 & 612 & 56 \\
\hline 51.0 & 27.39 & 1.4 & 2.18 & 73.95 & 59.71 & 80.74 & 721 & 56 \\
\hline
\end{tabular}

Controlled close loop system testing is done to charge the battery. Table 7 shows the results of controlled charging. From these results show fuzzy control is running to make the output voltage constant. From the results of the tests performed, the comparison of efficiency values on a controlled system (using FLC) and without controls looks different. The highest efficiency value when using a controlled system. Figure 8 below is a graph of efficiency value comparison of testing using FLC and without FLC. 


\begin{tabular}{|c|c|c|c|c|c|c|c|c|}
\hline $\begin{array}{c}\text { Vin } \\
(\mathbf{V})\end{array}$ & $\begin{array}{c}\text { Vo } \\
(\mathbf{V})\end{array}$ & $\begin{array}{c}\text { Iin } \\
(\mathbf{A})\end{array}$ & $\begin{array}{c}\text { Io } \\
(\mathbf{A})\end{array}$ & $\begin{array}{c}\text { Pin } \\
(\mathbf{W})\end{array}$ & $\begin{array}{c}\text { Pout } \\
(\mathbf{W})\end{array}$ & $\begin{array}{c}\tilde{\boldsymbol{\eta}} \\
(\%)\end{array}$ & lux & $\mathbf{D}$ \\
\hline 42.3 & 27.39 & 6.75 & 8.42 & 285.53 & 230.62 & 80.77 & 736 & 84 \\
\hline 43.7 & 27.24 & 5.64 & 7.65 & 246.47 & 208.39 & 84.55 & 840 & 76 \\
\hline 46.1 & 27.23 & 4.73 & 6.73 & 218.05 & 183.26 & 84.04 & 790 & 70 \\
\hline 48.4 & 27.32 & 4.13 & 6.03 & 199.89 & 164.74 & 82.41 & 837 & 68 \\
\hline 50.0 & 27.26 & 3.65 & 5.60 & 182.50 & 152.66 & 83.65 & 875 & 65 \\
\hline 51.2 & 27.21 & 3.10 & 4.80 & 158.72 & 130.61 & 82.30 & 846 & 61 \\
\hline 51.8 & 27.39 & 2.50 & 4.10 & 129.50 & 112.30 & 86.72 & 823 & 59 \\
\hline 52.1 & 27.19 & 2.13 & 3.40 & 110.97 & 92.45 & 83.31 & 942 & 58 \\
\hline 52.4 & 27.24 & 1.98 & 3.12 & 103.75 & 84.99 & 81.91 & 921 & 56 \\
\hline 52.3 & 27.32 & 1.53 & 2.64 & 80.01 & 72.12 & 90.14 & 863 & 56 \\
\hline 52.8 & 27.23 & 1.34 & 2.14 & 70.75 & 58.27 & 82.40 & 738 & 55 \\
\hline
\end{tabular}

From the tests performed, the efficiency value increases when using a controlled system. The fuzzy controls used are effective enough to increase the efficiency of the system.

\section{Conclusion}

Buck converter is very suitable to be implemented as a solar charger for batteries. The results of this research prove that buck converter can provide a stable output voltage. The output voltage generated by the buck converter can be used as a battery charging voltage by constant voltage method. Thus, such conditions can affect the durability and capacity of the battery that indirectly also affect the battery life. The addition of FLC causes the efficiency of the buck converter to increase from $84 \%$ to $91 \%$. This shows FLC is quite effective to improve the efficiency of solar charger.

\section{References}

1. P. K. C. Wong, A. Kalam and R. Barr, "Modelling and analysis of practical options to improve the hosting capacity of low voltage networks for embedded photo-voltaic generation," in IET Renewable Power Generation, vol. 11, no. 5, pp. 625-632, 412 2017. J. Clerk Maxwell, A Treatise on Electricity and Magnetism, 3rd ed., vol. 2. Oxford: Clarendon, 1892, pp.68-73.

2. Wahjono, Endro, Dimas Okky Anggriawan, Epyk Sunarno, Syechu Dwitya Nugraha, and Anang Tjahjono. "Maximum Power Point Tracking of Photovoltaic Module for Battery Charging Based on Modified Particle Swarm Optimization." International Review on Modelling and Simulations (IREMOS) 10, no. 1 (2017): 77-84.

3. A. Tjahjono, O. A. Qudsi, N. A. Windarko, D. O. Anggriawan, A. Priyadi and M. H. Purnomo, "Photovoltaic module and maximum power point tracking modelling using Adaptive Neuro-Fuzzy Inference System," 2014 Makassar International
Conference on Electrical Engineering and Informatics (MICEEI), Makassar, 2014, pp. 14-19.

4. G. Buja, R. K. Jha, M. Bertoluzzo and M. K. Naik, "Analysis and comparison of two wireless battery charger arrangements for electric vehicles," in Chinese Journal of Electrical Engineering, vol. 1, no. 1, pp. 50-57, Dec. 2015.

5. H. Sira-Ramirez and M. A. Oliver-Salazar, "On the Robust Control of Buck-Converter DC-Motor Combinations," in IEEE Transactions on Power Electronics, vol. 28, no. 8, pp. 3912-3922, Aug. 2013.

6. E. Guerrero, J. Linares, E. Guzman, H. Sira, G. Guerrero and A. Martinez, "DC Motor Speed Control through Parallel DC/DC Buck Converters," in IEEE Latin America Transactions, vol. 15, no. 5, pp. 819-826, May 2017.

7. H. K. Samitha Ransara, U. K. Madawala and T. H. Liu, "Buck converter based model for a brushless DC motor drive without a DC link capacitor," in IET Power Electronics, vol. 8, no. 4, pp. 628-635, 4 2015.

8. R. Silva-Ortigoza, V. M. Hernández-Guzmán, M. Antonio-Cruz and D. Muñoz-Carrillo, "DC/DC Buck Power Converter as a Smooth Starter for a DC Motor Based on a Hierarchical Control," in IEEE Transactions on Power Electronics, vol. 30, no. 2, pp. 1076-1084, Feb. 2015.

9. R. Silva Ortigoza, J. N. Alba Juarez, J. R. Garcia Sanchez, M. Antonio Cruz, V. M. Hernandez Guzman and H. Taud, "Modeling and Experimental Validation of a Bidirectional DC/DC Buck Power Electronic Converter- DC Motor System," in IEEE Latin America Transactions, vol. 15, no. 6, pp. 1043-1051, June 2017.

10. R. Silva Ortigoza, J. N. Alba Juarez, J. R. Garcia Sanchez, V. M. Hernandez Guzman, C. Y. Sosa Cervantes and H. Taud, "A Sensorless PassivityBased Control for the DC/DC Buck Converter- Inverter- DC Motor System," in IEEE Latin America Transactions, vol. 14, no. 10, pp. 4227-4234, Oct. 2016.

11. J. Linares-Flores, J. L. Barahona-Avalos, H. SiraRamirez and M. A. Contreras-Ordaz, "Robust Passivity-Based Control of a Buck-BoostConverter/DC-Motor System: An Active Disturbance Rejection Approach," in IEEE Transactions on Industry Applications, vol. 48, no. 6, pp. 2362-2371, Nov.-Dec. 2012.

12. N. Anandh, P. A. D'sa, M. V. Gautam and V. S. Sandeep, "Power quality estimation, analysis and improvement for uninterrupted power supply," 2016 International Conference on Control, Instrumentation, Communication and Computational Technologies (ICCICCT), Kumaracoil, India, 2016, pp. 26-31.

13. O. Gomozov, J. P. F. Trovão, X. Kestelyn and M. R. Dubois, "Adaptive Energy Management System Based on a Real-Time Model Predictive Control 
With Nonuniform Sampling Time for Multiple Energy Storage Electric Vehicle," in IEEE Transactions on Vehicular Technology, vol. 66, no. 7, pp. 5520-5530, July 2017.

14. Windarko, N. A., Qudsi, O. A., Tjahjono, A., Dimas, O. A., \& Purnomo, M. H. (2014, November). Optimized PI constant for current controller of grid connected inverter with LCL filter using genetic algorithm. In Electrical Engineering and Informatics (MICEEI), 2014 Makassar International Conference on (pp. 9-13). IEEE.

15. J. L. Russi, M. L. S. Martins, H. A. Grundling, H. Pinheiro, J. R. Pinheiro and H. L. Hey, "A unified design criterion for ZVT DC-DC PWM converters with constant auxiliary Voltage source," in IEEE Transactions on Industrial Electronics, vol. 52, no. 5, pp. 1261-1270, Oct. 2005.

16. M. E. Sahin and H. I. Okumus, "A fuzzy-logic controlled PV powered buck-boost DC-DC converter for Battery-Load system," 2012 International Symposium on Innovations in Intelligent Systems and Applications, Trabzon, 2012

17. G. Gupta and P. Gaur, "Fuzzy logic controlledpower factor corrected bridgeless buck boost converter-fed brushless DC motor drive," 2015 International Conference on Computer, Communication and Control (IC4), Indore, 2015

18. N. Ikken, A. Bouknadel, H. El Omari and H. El Omari, "Design and implementation of intelligent PI-fuzzy logic control for grid connected inverters," 2016 International Renewable and Sustainable Energy Conference (IRSEC), Marrakech, 2016 